\title{
Earnings Management Incentives and the Pricing of Discretionary
}

\section{Accruals}

\author{
Sondes Draief ${ }^{1}$ \\ ${ }^{1}$ Université de la Manouba, Institut Supérieur de Comptabilité et d'Administration des Entreprises, Tunisia \\ ${ }^{1}$ Université de Tunis, Laboratoire, Gouvernance d'Entreprise, Finance Appliquée et Audit, Tunisia \\ Correspondence: Sondes Draief, Institut Supérieur de Comptabilité et d'Administration des Entreprises, Campus \\ universitaire de la Manouba, Tunisia. E-mail: draiefsondess@yahoo.fr
}

Received: April 26, 2019

doi:10.5539/ijbm.v14n7p77
Accepted: May 20, 2019

Online Published: June 9, 2019

\begin{abstract}
The objective of this research is to investigate whether earnings management incentives influence the pricing of discretionary accruals. Specifically, we verify if growth opportunity, leverage, free cash flow, insider trading and financial distress are useful to investors to discriminate between opportunistic and informative earnings management.

Using a sample of 486 American firms for the period 2002-2010, we find that discretionary accruals are positively related to stock returns. This relation is more intensive in high growth firms and high levered firms. Indeed, these firms use more informative earnings management to communicate future prospects and good financial situation to external investors. However, discretionary accruals are negatively priced by investors in distressed firms. These firms have a greater incentive to manage earnings opportunistically to hide any financial problem. Likewise, we detect a negative relationship between discretionary accruals and stock returns in firms with excessive free cash flow revealing the opportunistic perspective of earnings management. Finally, we demonstrate that investors award positive (negative) value to discretionary accruals in case of insider buying (selling).
\end{abstract}

Keywords: discretionary accruals, stock returns, earnings management incentives, opportunism, signaling

\section{Introduction}

The affluent use of financial information by investors and financial analysts to assess firm shares stimulates managers to manipulate earnings and consequently influence market price and returns. It is therefore interesting to investigate how the stock market reacts to earnings management. Indeed, earnings management is possible through discretionary accruals since Generally Accepted Accounting Principles (GAAP) offer to managers the possibility to exercise their discretion over accounting accruals and manage earnings upward or downward according to their objectives.

Prior literature has widely investigated the association between earnings management through discretionary accruals and stock returns. However, empirical evidence is not conclusive. For instance, several studies (Balsam, Bartov, \& Marquardt, 2002; Siregar \& Utama, 2008) approve the opportunistic view of earnings management providing that managers use discretion only for their own profits rather than for the benefits of the stakeholders. Consequently, discretionary accruals are negatively priced by an efficient market.

Asymmetrically to the opportunistic approach, other researchers (Arya, Glover, \& Sunder, 2003; Farshadfar \& Monem, 2011; Robin \& Wu, 2015; Subramanyam, 1996) argue that discretionary accruals are informative and convey credible signal about future prospects. As a result, they are positively priced by the market.

Nevertheless, another stream of literature (Sloan, 1996; Xie, 2001) support the notion of mispricing by proving that investors overprice accruals and do not fully understand the negative implications of actual accruals on future earnings.

More recent studies in the accounting field (Habib, Uddin Bhuiyan, \& Islam, 2013; Robin \& Wu, 2015) assert that the market has to consider earnings management motivations when it evaluates accruals. Indeed, Rezaei and Roshani (2012) state that managers' incentives influence the type of earnings management. 
Earnings management incentives are generally classified as either opportunistic that attempt to mislead partners or informative that convey private information to market participants (Beaver, 2002). Consequently, the information content of discretionary accruals may depend critically on earnings management incentives as well as how the market explains this motivation. Assuming that the market is efficient, investors are expected to price positively (negatively) discretionary accruals used for informative (opportunistic) reasons.

In spite of its theoretical importance, researchers in this field are quite rare. Few studies linked the pricing of discretionary accruals to earnings management incentives. In this context, Gul, Leung, and Srinidhi (2000) are pioneers. The authors examine the effect of debt and growth opportunity on the pricing of discretionary accruals. They show that the positive pricing of discretionary accruals is stronger for high-growth firms than for low-growth firms. Nevertheless, the effect of debt on the relationship between discretionary accruals and stock returns is weak. Similarly, Robin and $\mathrm{Wu}$ (2015) show that positive discretionary accruals are positively priced by the market in high-growth firms and positively associated with future firm performance. Therefore, they approve the informational aspect of earnings management to convey good news to external investors.

In our research, we extend prior studies by linking market perception of discretionary accruals to different earnings management incentives. We consider a set of incentives that may point out the opportunistic or informative aspect of earnings management. To the best to our knowledge, this is the first paper to test the relationship between stock returns and discretionary accruals considering, at the same time, a set of earnings management incentives.

We extend the basic model of the pricing of discretionary accruals used in Subramanyam (1996). One criticism of Subramanyam's model is that it does not consider managers' incentives when examining the relationship between stock returns and discretionary accruals. We fill this gap by adding, as independent variables, the interaction between earnings management incentives and discretionary accruals. Assuming market efficiency, we argue that investors discriminate between opportunistic and informative earnings management and price discretionary accruals differently according to earnings management incentives.

The financial literature enumerates a set of motivations to push managers towards earnings management. We consider growth opportunities, leverage, free cash flow, insider trading and financial distress as factors that reflect earnings management incentives and that may help investors to assess the informational content of discretionary accruals.

Using a sample of 486 US listed firms from 2002 to 2010, we find that there is a significant variation in the pricing of discretionary accruals due to earnings management incentives. Hence, investors respond as if discretionary accruals have particular information content in each circumstance. However, pricing differently these accruals is not sufficient to support investors' rationality. Another possible explanation is that investors do not comprehend the information content of accruals and erroneously respond on reported accruals (functional fixation hypothesis). To strike out this alternative explanation, we study the association between earnings management and future performance. If discretionary accruals are likely to be correctly priced by investors, they are expected to be negatively (positively) associated with both current -year stock returns and future performance when they are used on opportunistic (informative) reasons.

The remainder of the paper is organized as follows. The second section discusses previous researches and develops testable hypotheses. The third section describes the data and methodology. The fourth section presents the results and sensitivity analysis. The last section provides concluding remarks.

\section{Literature Review and Hypothesis Development}

\subsection{The Pricing of Discretionary Accruals}

The accounting literature develops four possible outlooks to explain market reaction towards earnings management.

Under the efficient market hypothesis, three scenarios emerge: The informational view suggests that managers manage earnings to communicate private information about firm value. Hence, earnings management can enhance the value relevance of accounting numbers by providing an accurate prevision of future performance and reducing information asymmetry in the market (Arya et al., 2003). Such accruals are positively priced by investors.

As for the opportunism hypothesis, managerial discretion over accruals is a means to delay information and mislead outside investors. For example, managers can manage earnings upward to maximize their bonuses, to prevent adverse contractual consequences or to mask a firm's current declining performance. Consequently, rational investors price accruals negatively. 
Otherwise, the efficient hypothesis (Christie \& Zimmerman, 1994) suggests that earnings management is used to raise the aggregate wealth of contracting parties; namely shareholders, debt holders and managers.

At the opposite, the functional fixation hypothesis suggests that investors fail to decrypt the true cash flow repercussions of accounting numbers. Indeed, they are excessively optimistic about the future performance of firms when accruals are high and too pessimistic about the future performance of firms when accruals are low without considering their lower persistence. As a result, investors 'anticipations of future earnings are adjusted wrongly upward (downward) for firms with high (low) accruals.

The extant empirical evidence in this subject is somewhat ambiguous and conflicting.

In fact, Sloan (1996) consider that total accruals do not have the ability to predict future profitability. He suggests that accruals are enough subjective and depend strongly on managerial discretion and great one-time adjustments. Accordingly, he finds that the persistence of the accrual component is weaker than that of the cash flow component and that investors fail to correctly estimate their implications for future performance.

Using the Mishkin test (1983), Xie (2001) extends Sloan's finding and asserts that the overpricing of total accruals, by the market, is largely due to discretionary accruals that are used for altruistic reasons.

Nevertheless, Subramanyam (1996) points out that the stock market positively values discretionary accruals. The author suggests that two potential explanations are possible for this result. First, discretionary accruals reduce information asymmetry and communicate private information about firm performance. Therefore, they are correctly priced by the market. Second, discretionary accruals are opportunistic and irrelevant but evaluated by an inefficient market. To rule out from the opportunism hypothesis, Subramanyam (1996) investigates if current discretionary accruals forecast future cash flows, earnings, and dividends. He finds that discretionary accruals enhance the value relevance of earnings related to future performance. As a consequence, he concludes that discretionary accruals are a superior estimator of firm performance than cash flow that enhances the informational content of earnings. Indeed, Janin (2000) came to similar evidence while studying a sample of French firms, supporting the signal perspective that earnings management is a financial communication tool that improves earnings quality.

In the same line of thinking, several studies (Choi, 2016; Jiraporn, Miller, Yoon, \& Kim, 2008; Rezaei \& Roshani, 2012) support the informational perspective of earnings management. They indicate that earnings management is used to credibly convey private information about firm value. Thus, discretionary accruals positively affect future profitability.

However, Balsam et al. (2002) and Siregar and Utama (2008)find that discretionary accruals are negatively related to stock returns around the earnings announcement date, which means that the market considers discretionary accruals as opportunistic.

Assuming market efficiency, we consider that investors will price positively (negatively) discretionary accruals if they believe that earnings management is informative (opportunistic). Hence, the first hypothesis is formulated as follows:

$\mathrm{H}_{1}$ : Discretionary accruals influence stock returns.

\subsection{The Effect of Earnings Management Incentives on the Pricing of Discretionary Accruals}

Though their importance, previous researchers only focus their analysis on the pricing of discretionary accruals without regard to underlying motivation. In an attempt to deepen them, limited studies have sought whether the stock market differentiates the circumstances under which earnings management is for efficiency, informational or opportunistic reasons.

In this context, the Gul et al. (2000) study proves to be revealing in this area. The authors examine whether the pricing of discretionary accruals depends on growth opportunity level and debt. They demonstrate that the pricing of discretionary accruals is higher for high-growth firms than for firms in maturity. These results confirm that managers use discretionary accruals as a tool to communicate future growth prospects. However, the authors note that debt level negatively influences the pricing of discretionary accruals. The authors show further that the positive association between discretionary accruals and future performance is reinforced in high-growth firms but weakened in high-debt firms.

Recently, Robin and Wu (2015) extend this research and examine how discretionary accruals are priced in high growth firms. Given the high level of information asymmetry and the increased agency cost, managers of high growth firms should enhance the flow of corporate information to moderate these problems. Thus, discretionary accruals are aimed to send positive private information about future performance. The results reveal a positive 
association between abnormal returns and discretionary accruals. Thus, the signal conveyed by discretionary accruals is considered credible by the market.

Hosseini, Chalestori, Hi, and Ebrahimi (2016) focus on the magnitude of the association between earnings management and earnings response coefficient. They predict that this relationship depends on earnings management incentives. They consider three incentives; namely executive compensation plan, debt limit and decline in performance. However, they find that there is no relationship between these managerial motivations and earnings response coefficients. In other words, investors do not consider earnings management incentives at the time of earnings response.

Habib et al. (2013) conduct a study on a sample of New Zealand listed firms from 2000 to 2011. They document that financially distressed firms tend to manage earnings downward. Moreover, the authors demonstrate that the market positively prices discretionary accruals but such a pricing coefficient significantly reduces during the global financial crisis period. Therefore, the New Zealand market considers discretionary accruals to be informative during the non-crisis period and opportunistic in the crisis period.

On another side, Habib et al. (2013) investigate the stock market price response to earnings smoothness for firms operating in an environment of high uncertainty. They find a positive association between current stock returns and smoothed earnings. It means that smoothed earnings are useful because it reduces the information asymmetry, for firms operating in higher environmental uncertainty.

Other studies have attempted to look into the informational content of the discretionary accruals by linking it to the governance structure. In this context, Krishnan (2003) argued that reputed auditors (measured by Big 4 audit firm) are well able to detect opportunistic accounting practices and report irregularities to the financial market. Given their expertise, they can detect the informational component of accruals from noise. The author adds that the auditors' reputation increases the credibility of the financial statements and enhances the informative value of discretionary accruals. As a result, discretionary accruals in firms audited by BIG 4 are informative. Janin and Piot (2008) and Rezaei and Roshani (2012) come to the same conclusion respectively in France and Iran.

However, Nuryaman (2013) contests these results. Using a sample of Indonesian firms, he releases two important results. First, earnings management practices are opportunistic and are priced negatively by the capital market. Second, the negative relationship between stock returns and discretionary accruals is greater for firms audited by a Big 4, when compared with the firms audited by a non-Big 4 .

With reference to this field, we examine the pricing of discretionary accruals by considering alternative motivations of earnings management. We consider growth opportunities, leverage, free cash flow, insider trading, and financial distress as factors that reflect the opportunistic or the informative incentives of earnings management. Consequently, they affect the informational content of discretionary accruals.

Under the market efficiency hypothesis, investors infer the informational content of discretionary accruals, considering the underlying incentive, and act accordingly.

The effects of these factors are discussed below:

\subsubsection{The Effect of Growth Opportunity on the Pricing of Discretionary Accruals}

Based on prior research (Chang, Chen, Hsing, \& Huang, 2007; Core, 2001; Koussis \& Makrominas, 2015), information asymmetry and agency costs problems are intense in high-growth firms. As a consequence, these firms cannot access sufficiently to external financial sources. These problems could be moderated by raising the flow of information.

Many researchers (Bae \& Jo, 2007; Lee, Li, \& Yue, 2006) have proven that managers in high growth firms use discretionary accruals to alleviate the information asymmetry between insiders and externs and credibly communicate their private value-relevant foresight information to the investors. Such use of discretion is referred to as informational earnings management and is favorably perceived by investors (Gul, Chen, \& Tsui, 2003; McNichols \& Stubben, 2008; Robin \& Wu, 2015).

Nevertheless, the opposite assumption is that firms with more opacity may involve in opportunistic earnings management and send a false signal to mislead market participants. Indeed, controlling managerial discretion is difficult in a situation of information asymmetry. Hence, managers may be better able to manage earnings only to their own benefits (Thomas, 2002).

We are bowing rather the signaling perspective and think that high-growth firms have compelling reasons to convey credible signals about future prospects using discretionary accruals.

On the one hand, managers of growth firms avoid the false signal that may have harmful effects for them such as 
an increase in the cost of capital (Francis, LaFond, Olsson, \& Schipper, 2005). Indeed, high growth firms suffer from liquidity constraints and will be encouraged to divulge high quality of financial information.

On the other hand, managers may alter their reputation in financial markets even beyond the litigation concerns for firms. Consequently, opportunistic conduct has costs that may counterbalance benefits.

Therefore, we develop the following hypothesis:

$\mathrm{H}_{2}$ : The effect of discretionary accruals on stock returns is higher in high growth firms.

\subsubsection{The effect of Leverage on the Pricing of Discretionary Accruals}

The leverage may have an important role in restraining opportunistic earnings management. Based on agency theory (Jensen \& Meckling, 1976), debt reduces agency conflicts between shareholders and managers. For instance, increasing debt will drive a firm to use effectively the cash that can be used to pay debt interest periodically all the more the external monitoring generated by lenders. Therefore, managers should act to maximize firm value otherwise they will be penalized.

Empirically, Jelinek (2007), Moradi, Valipour, and Pahlavan (2012); (Omid, 2012) approve this proposal and find that increased leverage is associated with reduced opportunistic earnings management, thus confirming the disciplining role of debt in attenuating the agency conflict.

Likewise, Omid (2012) examines the discretionary accruals' capacity to communicate future prospects and focuses on the effect of debt level to strengthen this relationship in companies listed on the Tehran Stock Exchange. He finds a positive and significant relationship between discretionary accruals and future profitability confirming the informational perspective of earnings management. More interestingly, the results show that this relation is even stronger when the debt ratio increases. Therefore, earnings management is more efficient in firms with a high debt ratio than in other firms. This result approves the disciplinary role of debt in constraining managerial opportunism.

However, following an opportunistic scenario, managers of levered firms manage earnings opportunistically to avoid debt covenant default and camouflage the financial problem that high debt can cause (Beatty \& Weber, 2003; DeFond \& Jiambalvo, 1994; Dichev \& Skinner, 2002). Moreover, debt exacerbates the expropriation of minority shareholders by majority shareholders and this hurts good governance practices and debtholders value.

In this context, Liu and Jiraporn (2010) affirm that firms inflate earnings prior to bond issues. They show that such firms can issue debt at a low cost and bondholders fail to comprehend the managed earnings when they price new debts. This finding is confirmed by Alissa, Bonsall IV, Koharki, and Penn Jr (2013).

Based on the discussion above, earnings management at high debt levels may adversely affect the discretionary accruals -stock returns relationship.

We are looking more towards the efficient suggestion for two reasons:

First, referring to agency theory (Jensen and Meckling, 1976; Jensen, 1986) when leverage increases, there is an alignment of interests between outside shareholders and managers that should act to improve firm performance. All the more, debt generates intense external monitoring by debt holders that severely penalize firms in case of falsification or disrespect of debt agreement. Thus, higher debt firms tend to use informative earnings management, and that implies more confidence in financial reports.

Second, considering the signaling theory (Ross, 1977), managers use debt to convey inside information about firm performance and its capacity to support high debt levels. Another way for a high-quality firm to communicate private information is by using informative earnings management that enhances earnings informativeness. Taken together, debt and accruals can be viewed as reliable signaling mechanisms of good financial position. Thus, the market will respond positively to discretionary accruals.

Consequently, our hypothesis is the following:

$\mathrm{H}_{3}$ : The effect of discretionary accruals on stock returns is higher in high debt firms.

\subsubsection{The Effect of Free Cash Flow on the Pricing of Discretionary Accruals}

According to Jensen (1986), excessive free cash flow creates conflicts between managers and shareholders' interests. In fact, managers waste these resources by investing in projects that present negative net present value (NPV) (overinvestment problem) instead of rising dividends or investing in projects with low returns. This behavior deteriorates firm performance (Smith \& Kim, 1994).

Several studies (Bhundia, 2012; Nekhili, Amar, Chtioui, \& Lakhal, 2016; Rusmin, W. Astami, \& Hartadi, 2014) 
document that firms with a high level of free cash flow tend to hide the consequence of investments in projects with negative NPV and meet investors' profit expectations by managing earnings and presenting inflated profits.

We believe that the opportunistic incentives of earnings management would dominate in an overinvestment setting to mislead users. Considering the possible deterioration of firm future performance due to overinvestment, the manager manipulates earnings opportunistically to hide poor performance and orientate market actors to act in a certain manner.

Hence, we expect that this opportunistic behavior is detected by rational investors and causes a decrease in stock price. Then, we hypothesize the following:

$\mathrm{H}_{4}$ : The pricing of discretionary accruals is lower in firms with excessive free cash flow.

\subsubsection{The Effect of Insider Trading on the Pricing of Discretionary Accruals}

The commonly held belief is that insider trading influences future share price. When insiders purchase the stocks, they do so because they anticipate an increase in the stocks' value. Thus, it is thought that insider buying is frequently followed by a stock price increase in security markets. However, when they sell, they do so for several reasons and not just because they forestall a drop in the firm's share price. As a consequence, insider buying may be a good indicator of future performance, but the interpretation of insider selling is not so obvious.

The predominance of insider trading informational advantage has been linked to its ability to influence reported earnings ((Messod Daniel Beneish, Press, \& Vargus, 2004; Olsen \& Zaman, 2013).

In this line of thinking, Jaggi and Tsui (2007) found a positive association between earnings management and insider selling, in the Korean context. They confirm that insiders are active traders in that they use their informational advantage to influence stock prices through earnings management.

Similarly, Del Brio, Lopes-e-Silva, and Perote (2016) note that insiders use their discretion and choose opportunistically the time of their transactions to attain higher returns than outsiders.

Messod D Beneish and Vargus (2002) assert that signals contained in insider trading are useful to distinguish between opportunistic and informative earnings management and evaluate the financial information quality.

Opportunism predicts that the buying trades of insiders decrease in frequency relative to the selling trades as earnings are managed upward. Therefore, managers use their discretion to hide current earnings and dupe outside investors. This suggestion was approved by Olsen and Zaman (2013)

In return, the signaling assumption implies that managers use discretionary accruals to communicate their private information about the future of the firm. This assumption implies that insiders will buy (sell) more when discretionary accruals are managed upward (downward).

Considering that insiders may have an informational advantage relative to other market interveners and that their buying (selling) choice will be established on the anticipations of an increase (decrease) in earnings, we expect that rational investors appreciate (penalize) firms that manage earnings upward following buying (selling) trades of insiders.

Accordingly, I express the following hypothesis:

$\mathrm{H}_{5}$ : The effect of discretionary accruals on stock returns is higher (lower) in case of buying (selling) trades of insiders.

\subsubsection{The Effect of Financial Distress on the Pricing of Discretionary Accruals}

A considerable and determined drop in a firm's financial performance may probably cause severe financial problems that push managers to engage in earnings management. This is in order to hide a loss that can be very costly impairing access to credit and causing an aggressive decline in the share price.

Many researches have empirically studied the earnings management strategy of financially distressed firms. Rosner (2003) notes that firms that become bankrupt ex-post but do not appear distressed ex-ante, manage earnings upward to stave -off covenant violations.

Cheng and Warfield (2005) affirm that managers of distressed firms tend to raise earnings to camouflage poor performance. Managers may act in this way because their stock-based remuneration is influenced by the negative market reaction to lower-than-expected earnings for fear to lose their post or alter their reputation.

Other studies (Charitou, Lambertides, \& Trigeorgis, 2007; DeAngelo, DeAngelo, \& Skinner, 1994; Habib et al., 2013) document that financially distressed firms are enlisted in income-decreasing earnings management strategies. This may be due to big-bath practice chosen by managers during the distress period. In fact, this 
practice permits firms to provide positive earnings in the subsequent period as accruals reverse.

Otherwise, Howe and Houston (2015) suggest that distressed firms manage earnings both upward and downward. In fact, managers have incentives to manage earnings upward to preserve their job and reputation. Moreover, distressed firms are more likely to depreciate assets than other firms and have therefore large negative accruals.

Given that financial distress is considered a significant threat to the firm viability, it is therefore important to analyze investors' response to accounting information in this case. However, the market pricing of discretionary accruals for distressed firms is very limited.

Habib et al. (2013) find that investors penalize distressed firms that manage earnings downward. Investors consider that earnings management choice is opportunistic rather than informative and poses a significant risk for them.

We foresee that investors are less confident in the quality of financial reporting of distressed firms. Since we focus on upward earnings management, we judge that investors link discretionary accruals more with managerial opportunism that aims to delay investors and creditors' financial loss and mask a deteriorating performance.

The following hypothesis, therefore, is developed:

$\mathrm{H}_{6}$ : The pricing of discretionary accruals is lower in financially distressed firms.

\section{Research Methodology}

In this section, we describe the sample and we present, then, the model used to verify our hypotheses.

\subsection{Sample}

Our analysis is based on a sample of 486 listed American firms from 2002 to 2010 . We excluded financial institutions. Stock prices were extracted from Yahoo Finance. Financial data were gathered manually from annual reports, balance sheets and income statements. This information is available on the SEC website.

\subsection{Regression Model}

Our principal analysis is conducted by a regression of stock returns on different components of earnings (cash flows, non-discretionary accruals, and discretionary accruals), and the interaction between discretionary accruals and managerial incentives. We estimate the equation below which extends the basic pricing equation of discretionary accruals used in Subramanyam's study (1996) by incorporating earnings management incentives.

$$
\mathrm{RET}_{\mathrm{it}}=\mathrm{a}_{1}+\mathrm{a}_{2} \mathrm{CFO}_{\mathrm{it}}+\mathrm{a}_{3} \mathrm{NDA}_{\mathrm{it}}+\mathrm{a}_{4} \mathrm{DA}_{\mathrm{it}}+\mathrm{a}_{5} \mathrm{DA}^{*} \mathrm{EMI}_{\mathrm{it}}+\mathrm{a}_{6} \mathrm{EMI}_{\mathrm{it}}+\text { Control variables }_{\mathrm{it}}+\mathrm{e}_{\mathrm{it}}
$$

$\mathrm{i}=(1 \ldots \ldots .486) ; \mathrm{t}(2002 \ldots \ldots .2010)$

RET: is stock returns calculated over a 12 month window beginning after the third month of fiscal year end and ending on 3 months after the fiscal-year end.; $\mathrm{RET}_{\mathrm{it}}=\left(\mathrm{P}_{\mathrm{it}}-\mathrm{P}_{\mathrm{it}-1}+\mathrm{D}_{\mathrm{it}}\right) / \mathrm{P}_{\mathrm{it}-1}$ where $\mathrm{P}_{\mathrm{it}}$ is the stock price of firm $\mathrm{i}$ at time $t$, and $\mathrm{D}_{\mathrm{it}}$ is the dividend of firm $\mathrm{i}$ at year $\mathrm{t}$ );

EMI: Earnings management incentives;

CFO: cash flows from operating activities;

NDA: non-discretionary accruals;

DA: discretionary accruals.

Those three last variables are deflated by the beginning-of-year total assets.

The coefficient $a_{4}$ illustrates the market pricing of DA. The coefficient on $a_{4}$ will be positive (negative) if DA is seen as informative (opportunistic) by investors.

The combined coefficient $\left(a_{4+} a_{5}\right)$ illustrates the market pricing of DA considering the earnings management incentives.

\subsubsection{Earnings Management Measure}

We use the Kothari, Leone and Wasley (2005) model to estimate earnings management. Discretionary accruals are estimated as shown in equation (2):

$$
\mathrm{TAC}_{\mathrm{i}, \mathrm{t}}=\alpha_{0}+\alpha_{1} 1 / \mathrm{TA}_{\mathrm{i}, \mathrm{t}-1}+\alpha_{2}\left(\Delta \mathrm{REV}_{\mathrm{i}, \mathrm{t}}-\Delta \mathrm{REC}_{\mathrm{i}, \mathrm{t}}\right)+\alpha_{3} \mathrm{PPE}_{\mathrm{i}, \mathrm{t}-1}+\alpha_{4} \mathrm{ROAi}_{\mathrm{t}-1}+\mathrm{e}_{\mathrm{i}, \mathrm{t}}
$$

Where:

TAC: $\quad$ Total accruals $=$ the difference between net profit and cash flow from operating activities;

TA: Total Assets; 
$\triangle \mathrm{REV}$ : The change in revenue between $\mathrm{t}$ and $\mathrm{t}-1$;

$\triangle \mathrm{REC}:$ The change in accounts receivable between $\mathrm{t}$ and $\mathrm{t}-1$;

PPE: Gross property, plant and equipment;

ROA: Return on Assets (ROA= Net income/Total assets).

$\triangle \mathrm{REV}, \triangle \mathrm{REC}, \mathrm{PPE}$ and the intercept term are deflated by the beginning of period assets. Non-discretionary accruals (NDA) are calculated by incorporating $\hat{\alpha}_{1}, \hat{\alpha}_{2}, \hat{\alpha}_{3}$ and $\hat{\alpha}_{4}$ from the regression equation. Discretionary accruals (DA) denote the residual term.

It's worth noting that we concentrate only on the information content of positive discretionary accruals without considering negative discretionary accruals. We argue that the information content of earnings management is predominantly in the positive discretionary accruals scenario. Thus, managers tend to increase earnings to signal future favorable performance, or to camouflage poor performance or to attend their own interest.

\subsubsection{Independent Variables}

The independent variables are the interaction term between discretionary accruals and earnings management incentives including growth opportunity, leverage free cash flow, insider trading and financial distress.

The definition of the above variables is given in Table 1 .

Table 1. Definition of variables

\begin{tabular}{|c|c|c|}
\hline Variable & Definition & Measure \\
\hline GROWTH & Growth opportunity & Tobin's q = market value/replacement values of a firm's assets. \\
\hline LEV & Leverage & total debt /total asset \\
\hline FCF & Free cash flow & $\begin{array}{l}\text { Operating profit before depreciation - total tax paid - interest expense - } \\
\text { dividend) / total assets. }\end{array}$ \\
\hline BUY & Insiders' buying trades & $\begin{array}{l}\text { Dummy variable equal to } 1 \text { if insiders' buying trades increase between } t-1 \text { and } t \text { and } 0 \\
\text { otherwise. }\end{array}$ \\
\hline SELL & Insiders' selling trades & $\begin{array}{l}\text { Dummy variable equal to } 1 \text { if insiders' selling trades increase between } \mathrm{t}-1 \text { and } \mathrm{t} \text { and } 0 \\
\text { otherwise }\end{array}$ \\
\hline DISTRESS & Financial distress & $\begin{array}{l}\text { Altman's } \mathrm{Z} \text { score }=1.2 \mathrm{X} 1+1.4 \mathrm{X} 2+3.3 \mathrm{X} 3+0.6 \mathrm{X} 4+\mathrm{X} 5 \text { where } \mathrm{X} 1 \text { is working } \\
\text { capital divided by total assets, } \mathrm{X} 2 \text { is retained earnings divided by total assets, } \mathrm{X} 3 \text { is } \\
\text { earnings before interest and taxes divided by total assets, } \mathrm{X} 4 \text { is the market value of } \\
\text { equity divided by the book value of total debt, and } \mathrm{X} 5 \text { is sales divided by total assets. }\end{array}$ \\
\hline
\end{tabular}

\subsubsection{Control Variables}

In addition to the variables of interest defined above, we include in the model some control variables namely, firm size (SIZE), growth opportunity, leverage, free cash flow, insider trading and financial distress. Firm size is the natural logarithm of the end of year market capitalization. We control for firm size because prior literature shows that size is a proxy for a firm's risk and information environment (Ohlson, 1980).

\section{Results}

All statistical processing was carried out on the STATA software (version SE 11.2)

4.1 Descriptive Analysis and Univariate Analysis

Table 2 provides descriptive statistics of stock returns, earnings components, and managerial incentives. 
Table 2. Descriptive statistics

\begin{tabular}{|c|c|c|c|c|c|}
\hline Variables & Mean & Median & Maximum & Minimum & Std. Dev. \\
\hline RET & 0.167 & 0.079 & 7.621 & -0.158 & 0.373 \\
\hline $\mathrm{CFO}$ & 0.063 & 0.058 & 0.257 & -0.114 & 0.119 \\
\hline NDA & 0.084 & 0.064 & 0.206 & -0.236 & 0.274 \\
\hline DA & 0.014 & 0.009 & 0.504 & -0.183 & 0.146 \\
\hline GROWTH & 2.145 & 3.472 & 6.35 & 0.011 & 2.853 \\
\hline FCF & 0.069 & 0.286 & 1.672 & -5.484 & 0.953 \\
\hline LEV & 0.338 & 0.472 & 0.992 & 0.011 & 0.204 \\
\hline DISTRESS & 0.113 & 0.292 & 1.101 & -4.17 & 0.792 \\
\hline SIZE & 20.868 & 16.118 & 27.420 & 2.620 & 2.057 \\
\hline Variables & & \multicolumn{2}{|c|}{ Proportion of Dummy $=1$} & \multicolumn{2}{|c|}{ Proportion of Dummy $=0$} \\
\hline BUY & & \multicolumn{2}{|c|}{0.41} & \multicolumn{2}{|c|}{0.58} \\
\hline SELL & & \multicolumn{2}{|l|}{0.58} & \multicolumn{2}{|l|}{0.41} \\
\hline
\end{tabular}

According to the table, returns have an average of $16.7 \%$ with a standard deviation of $37.3 \%$. The DAC range from a minimum of $-18.3 \%$ to a maximum of $50.4 \%$ of total assets with a mean of $1.4 \%$. The means of NDA and CFO are about 0.084 and 0.0673 respectively and are comparable to those represented in other researchers such as Subramanyam (1996) and Krishnan (2003). Almost $60 \%$ of the firms in the sample report buying trades of insiders. The average value of log assets is about 20.868. Sample observations are not highly leveraged. Average growth is higher than 1 indicating that companies have more growth options than assets in place. This result is expected to the extent that our sample belongs to fortune 1000 and therefore has strong investment opportunities.

Table 3. Pearson Correlation matrix

\begin{tabular}{|c|c|c|c|c|c|c|c|c|c|}
\hline & $\mathrm{CFO}$ & $\mathrm{NDA}$ & DA & GROWTH & FCF & LEV & SIZE & BUY & DISTRESS \\
\hline $\mathrm{CFO}$ & 1 & & & & & & & & \\
\hline NDA & $-0.018^{*}$ & 1 & & & & & & & \\
\hline $\mathrm{DA}$ & $-0.261 * *$ & $-0.097 *$ & 1 & & & & & & \\
\hline GROWTH & 0.06 & -0.043 & $0.248 * * *$ & 1 & & & & & \\
\hline FCF & $0.126^{*}$ & -0.005 & $0.135^{* *}$ & -0.05 & 1 & & & & \\
\hline LEV & $-0.114 *$ & $0.153 *$ & $0.147 * *$ & -0.183 & $0.158^{* *}$ & 1 & & & \\
\hline SIZE & $0.167^{* *}$ & -0.002 & $0.096^{* * *}$ & $0.054 *$ & 0.112 & $0.203 * *$ & 1 & & \\
\hline BUY & 0.154 & $-0.012 *$ & $0.115^{*}$ & $-0.212 * *$ & 0.042 & $0.167 * *$ & -0.002 & 1 & \\
\hline DISTRESS & -0.022 & 0.018 & $0.187 * *$ & $0.156^{*}$ & $0.116^{*}$ & $0.361 * *$ & -0.05 & $-0.174 *$ & 1 \\
\hline VIF & 1.01 & 1.12 & 1.04 & 1.68 & 1.54 & 1.12 & 1.001 & 1.02 & 1.58 \\
\hline
\end{tabular}

$* * *$ Significant at $1 \% ; * *$ significant at $5 \% ; *$ Significant at $10 \%$.

Table 3 reports the Pearson correlation among the model's independent variables and the variance inflate factor (VIF) values. $D A$ is positively correlated with all earnings motivations. Across this table, the pairwise correlations between CFO and DA are -0.261 and between CFO and NDA are -0.018; which is consistent with the accruals' smoothing nature. All Pearson coefficients correlations among independent variables are relatively low. We include all the independent variables in one regression since no problem of multicolinearity exists. The VIF confirms these results. The values are around 1 which is far below the critical value of 10 . Therefore, the effect of multicolinearity is negligible.

\subsection{Regression Results}

Before applying regression on data, there are some tests that must be fulfilled when we use a panel data set.

- $\quad$ Fisher test: this test aims to check the existence of individual effects in our data. We test the null hypothesis of homogeneity: there is no individual effect. The result is an F-statistic. $F=5.75$ (Prob $>F$ is $<0.001$ ). We reject then the null hypothesis and we deduct the existence of individual effects. 
- Hausman test: it is a specification test that determines whether two estimations' coefficients are statistically different. This test is conducted to identify the nature of the individual effects (fixed or random), and consequently, specify which technique is more appropriate to our model.

- The results reveal that $\mathrm{Chi}^{2}=1441.47$. $\mathrm{Prob}>\mathrm{Chi}^{2}$ is $<0.05$. The null hypothesis about the existence of random effects ( $\mathrm{p}$-value $=0.000<0.05$ ) is rejected. So, the model has been estimated as fixed effects.

- Heteroscedasticity test: Breush-Pagan test is conducted to test the null hypothesis of homoscedasticity that all coefficients of the regression of squared residuals are equal to zero which implies the constancy of the variance of each individual error. The test show that $\mathrm{Prob}>\mathrm{chi}^{2}<0.01$. Thus, we reject the null hypothesis and we conclude the presence of heteroscedasticity.

- Autocorrelation test: in panel data, it is also required to verify the presence of correlation between error terms. The Wooldridge test for autocorrelation is used to check that the sum of the squares of correlation coefficients between errors is nearly zero. The null hypothesis is the independence of residues between individuals. The test show $\mathrm{F}(1.420)=959.127$ and $\mathrm{p}$-value $<0.001$ leading us to reject the null hypothesis of no autocorrelation

Taking into account problems detected by the tests above, namely heteroscedasticity and autocorrelation of errors, the Generalized Least Squares method is used to overcome these problems.

Table 4 reports the estimation results for the model specified.

Table 4. GLS regression of stock returns on discretionary accruals conditional on earnings management incentives

\begin{tabular}{llll}
\hline $\begin{array}{l}\text { Dependent variable: RET } \\
\text { Independent variables }\end{array}$ & Coefficient & $\mathrm{Z}$ & Prob. $>\mathrm{Z}$ \\
\hline CFO & 0.368 & 2.59 & 0.051 \\
NDA & 0.167 & 0.56 & 0.424 \\
DA & 0.352 & 8.29 & 0.000 \\
DA*GROWTH & 0.166 & 2.85 & 0.042 \\
DA*LEV & 0.145 & 3.21 & 0.025 \\
DA*FCF & -0.378 & -8.46 & 0.000 \\
DA*BUY & 0.166 & 10.74 & 0.000 \\
DA*SELL & -0.282 & -8.01 & 0.000 \\
DA*DISTRESS & -0.406 & -9.24 & 0.000 \\
Control Variables & & & \\
GROWTH & 0.426 & 5.93 & 0.000 \\
FCF & -0.721 & -2.25 & 0.059 \\
LEV & -0.034 & -0.63 & 0.336 \\
DISTRESS & 0.056 & 0.41 & 0.531 \\
BUY & 0.137 & 8.15 & 0.000 \\
SELL & -0.258 & -6.97 & 0.000 \\
SIZE & 0.263 & 3.51 & 0.021 \\
INTERCEPT & 0.231 & 3.69 & 0.019 \\
\hline
\end{tabular}

Overall, the results corroborate our hypothesis. We show that the market positively prices discretionary accruals. This evidence reveals that earnings management is appreciated by investors that consider it informational to communicate useful information about firm performance. This result is consistent with the findings of Subramanyam (1996). More interestingly, we show that the pricing of $D A$ depends on managerial incentives for discretionary accounting choices.

Consistent with many US studies, we show that the positive association between discretionary accruals and stock returns is greater in high growth firms. Thus, according to investors, accruals are informative in high growth firms. They are used to reduce the high level of information asymmetry, improve earnings quality and convey credible signal about the firm's future prospects.

As expected, the coefficient on DA* LEV is positive. This implies that investors believe in the discipline role of debt in constraining managerial opportunism and assume that high debt firms engage in efficient earnings management to signal their good financial situation. Indeed, levered firms are severely monitored by creditors 
that drive the firm to use the cash efficiently otherwise they penalize it by increasing, for example, interest rate, claiming early payment or requiring additional restriction.

Consistent with the free cash flows hypothesis, we show that discretionary accruals are priced negatively when firms accumulate a high level of free cash flow. This result confirms that investors penalize opportunistic manipulations. They forestall that firms with excessive free cash flow use opportunistic earnings management more than other firms to hide the fall in firm performance due to the waste of resources through ineffective investments.

Empirical findings show that buying trades of insiders increase the informative value of discretionary accruals. Indeed, buying trades reveal that insiders trust in the firm's prospects and consequently enhance investors' confidence in financial reporting quality. That is why investors associate discretionary accruals more with efficient signaling than managerial opportunism.

In contrast, we detect a negative association between discretionary accruals and stock returns in case of selling trades of insiders. When insiders time their selling trades with earnings management upward, this prevents the opportunistic practices on earnings management that tend to delude investors with wrong information.

As hypothesized $\left(\mathrm{H}_{6}\right)$, we find that discretionary accruals are negatively priced by the market in distressed firms. Indeed, earnings management reveals here the managerial opportunism that tends to delay financial problems. As a consequence, discretionary accruals reduce the reliability of financial statements and confidence in the financial market.

Lastly, we show that CFO are positively and significantly associated with stock returns. This result appears in line with Subramanyam (1996), which means that firms with high cash flows from operations also have high stock returns. However, the effect of NDA is insignificant.

Our results confirm that investors respond differently to discretionary accruals in different circumstances. Thus, rational investors recognize the signals conveyed by discretionary accruals, considering the underlying incentive, and price shares accordingly. However, this evidence does not imply that investors correctly price discretionary accruals. Under the functional fixation hypothesis, it is not easy for market participants to really comprehend the intention around management discretion and hence to incorporate all relevant information into market prices. Thus, discretionary accruals may be erroneously priced by the market in the current period (Sloan, 1996).

To test whether the market efficiently prices or misprices discretionary accruals, we examine the association between current period discretionary accruals and future performance.

\subsection{Robustness Test}

As discussed above, the obtained results may be due to a wrong interpretation from investors. To rule out market mispricing, we test whether current discretionary accruals help predict future performance considering evidently earnings management incentives. We estimate the following model:

$$
\mathrm{ROA}_{\mathrm{it}+1}=\alpha_{1}+\alpha_{2} \mathrm{CFO}_{\mathrm{it}}+\alpha_{3} \mathrm{NDA}_{\mathrm{it}}+\alpha_{4} \mathrm{DA}_{\mathrm{it}}+\alpha_{5} \mathrm{DA} * \mathrm{EMI}_{\mathrm{it}}+\alpha_{6} \mathrm{EMI}_{\mathrm{it}}+\text { Control variables } \mathrm{it}_{\mathrm{it}}+\mathrm{e}_{\mathrm{it}}
$$

We measure future performance by return on asset (ROA) on $\mathrm{t}+1$; ROA $=$ Net income/ Total asset.

The independent variables are the same already used in the previous model.

The combined coefficient $\left(\alpha 4_{+} \alpha_{5}\right)$ captures the predictive ability of $D A$ considering the underlying motivation. The higher this coefficient, the more information about future performance is included in the current managerial incentive.

The empirical results are displayed in table 5. For brevity reasons, we report only the key variables. 
Table 5. GLS regression of future performance on discretionary accruals conditional on earnings management incentives

\begin{tabular}{llll}
\hline Dependent variable: ROA $_{\mathrm{t}+1}$ & & & \\
\hline Independent variables & Coefficient & $\mathrm{Z}$ & Prob. $>\mathrm{Z}$ \\
\hline CFO & 0.136 & 7.16 & 0.000 \\
NDA & 0.068 & 0.85 & 0.232 \\
DA & 0.266 & 17.42 & 0.000 \\
DA*GROWTH & 0.095 & 2.16 & 0.055 \\
DA*LEV & $1.69 \mathrm{e}^{-05}$ & 1.81 & 0.071 \\
DA*FCF & -0.378 & -8.46 & 0.000 \\
DA*BUY & 0.178 & 5.38 & 0.000 \\
DA*SELL & 0.115 & 6.14 & 0.000 \\
DA*DISTRESS & -0.257 & -4.49 & 0.001 \\
\hline
\end{tabular}

Our results indicate that discretionary accruals are positively and significantly related to future performance. This evidence approves that discretionary accruals improve the ability of earnings to reveal real performance and detect information not reflected by non-discretionary accruals. Moreover, we show that this relationship depends on earnings management incentives.

In fact, the coefficient of DA*GROWTH is significantly positive. This result appears in line with Robin and Whu (2015) confirming that discretionary accruals in high growth firms convey credible information about future favorable prospects and alleviate the problem of information asymmetry. This result confirms that investors are able to comprehend signals about future performance and price discretionary accruals at a premium.

Findings show also that discretionary accruals are negatively associated with future performance in the free cash flow situation. Earnings management is motivated by managerial opportunism in case of excessive free cash flow and has, therefore, an adverse impact on future performance. This evidence approves that investors perceive the opportunistic intention in these firms and penalize them.

As shown in table 5, our results reveal that future performance is negatively associated with discretionary accruals in case of financial distress. This result supports hypothesis 6 that earnings management by distressed firms reduces earnings quality and weakens future performance.

The next results suggest that the association between future performance- discretionary accruals strengthens in case of insider buying. Following, we confirm our previous results that upward earnings management jointly with insiders' share purchases are signals of an expected improvement in future unmanaged earnings.

These results support our finding that investors adequately predict future performance as they know managers intentions beforehand and price earnings management consequently.

Nevertheless, it seems that some incentives are ambiguous and not well understood by investors that have sometimes an excess of trust in accounting numbers. Contrary to expectations, the relationship between discretionary accruals and future performance in levered firms is very weak implying that investors overprice discretionary accruals in high debt firms. It appears that discretionary accruals of high-debt firms contain less private information about the financial situation than previously expected by investors. This result may have several reasons. Obviously, debt is a disciplinary and signaling mechanism; however, it can constitute a financial stressor that forces managers to manage earnings opportunistically. Indeed, levered firms face more pressures from debt holders to respect debt agreements and avoid risk default. Moreover, levered firms incur greater underinvestment problems which handicap them to face the competition. These causes add noise to the managed earnings and degrade the accruals' predictive capacity.

Strangely, discretionary accruals are positively associated with future performance in case of insider selling. We argue that this trade is not easy to interpret because it does not convey by default an opportunistic earnings management practice and may be due to another cause.

\section{Conclusion}

The aim of this research is to extend the existing literature on the pricing of discretionary accruals and market efficiency by testing the effect of earnings management motivations on the pricing of discretionary accruals.

Based on the assumptions of the strong efficiency of financial markets, we argue that rational investors may 
assign a positive (negative) value of discretionary accruals used for informational (opportunistic) reasons. We consider growth opportunities, leverage, free cash flow, insider trading and financial distress as incentives of earnings management that may influence the informational content of discretionary accruals.

We show that investors assign a positive value to discretionary accruals, which is consistent with Subramanyam (1996). Furthermore, we provide evidence that the association between discretionary accruals and stock returns depend critically on earnings management incentives. This leads to approve investors' rationality to price discretionary accruals.

Indeed, we show that discretionary accruals are positively priced by the market in high growth firms. This implies that managers of growing firms use informative earnings management to reduce the high level of asymmetric information and communicate private information about firms' future perspective.

Likewise, we find that the pricing of discretionary accruals is higher in case of insider buying. Otherwise, insiders' share purchase means that insiders believe strongly in firm's projects and make more informational use of accruals to signal good financial position. However, insider selling decreases the pricing of discretionary accruals. Investors associate in this case discretionary accruals to managerial opportunism.

In addition, investors positively price discretionary accruals in high levered firms. This indicates that investors' confidence in financial reporting increases in high levered firms because the opportunistic behavior of managers is constrained due to lenders' control.

In contrast, earnings management is detrimental and negatively priced by the market in case of excessive free cash flow. We conclude that rational investors are aware of opportunistic manipulations that aim to hide the fall in firm performance due to overinvestment.

Moreover, investors assign a negative value to discretionary accruals in distressed firms. Consequently, investors forestall that managers of distressed firms manipulate earnings upward to conceal poor financial performance and preserve their stock-based compensation.

We further conduct robustness tests to check whether the current discretionary accruals help to predict future performance. This aims to mitigate the functional fixed hypothesis that the market reacts automatically to total earnings and that discretionary accruals are wrongly priced (Sloan. 1996).

Overall, the results deny the investor's inability to comprehend accounting information as reported by the functional fixation hypotheses. We find that discretionary accruals are positively correlated with future performance confirming the informative perspective of earnings management. This relationship is stronger in high growth firms and in the case of buying trades of insiders.

Additionally, we notice that discretionary accruals negatively affect future performance in firms with high free cash flow and in distressed firms confirming the opportunistic aspect of earnings management.

Those results confirm the argument that market participants are sophisticated enough to prevent the persistence of discretionary accruals.

Nevertheless, our results show that the association between discretionary accruals and future performance, in high levered firms, is positive but very weak. Likewise, selling trades are not well comprehended by investors. In fact, contrary to our anticipations, discretionary accruals are positively associated with future performance in selling trades situation.

It seems that the information content of these discretionary accruals is not so obvious for the market which incorporates in the price a part of the information (noise) and fails to identify the other part that makes accruals less (more) predictive.

The results of this study are very important for market participants. They can be used as input for them to be aware of earnings management incentives as they make their valuation decisions.

This research can be improved in several ways. First, the relation between earnings management and stock returns can be extended by adding other earnings management incentives such as beating benchmarks and considering the effect of corporate governance practices. Second, it would be interesting to examine if investors efficiently price or misprice real earnings management. Third, we can examine whether investors' sophistication can affect earnings management practices.

\section{References}

Alissa, W., Bonsall IV, S. B., Koharki, K., \& Penn Jr, M. W. (2013). Firms' use of accounting discretion to influence their credit ratings. Journal of accounting and economics, 55(2-3), 129-147. 
https://doi.org/10.1016/j.jacceco.2013.01.001

Arya, A., Glover, J. C., \& Sunder, S. (2003). Are unmanaged earnings always better for shareholders? Accounting Horizons, 17, 111-116.

Bae, S. C., \& Jo, H. (2007). Underwriter warrants, underwriter reputation, and growth signaling. Review of Quantitative Finance and Accounting, 29(2), 129-154. https://doi.org/10.1007/s11156-007-0030-2

Balsam, S., Bartov, E., \& Marquardt, C. (2002). Accruals management, investor sophistication, and equity valuation: Evidence from 10-Q filings. Journal of Accounting Research, 40(4), 987-1012. https://doi.org/10.1111/1475-679X.00079

Beatty, A., \& Weber, J. (2003). The effects of debt contracting on voluntary accounting method changes. The Accounting Review, 78(1), 119-142. https://doi.org/10.2308/accr.2003.78.1.119

Beaver, W. H. (2002). Perspectives on recent capital market research. The Accounting Review, 77(2), 453-474. https://doi.org/10.2308/accr.2002.77.2.453

Beneish, M. D., \& Vargus, M. E. (2002). Insider trading, earnings quality, and accrual mispricing. The Accounting Review, 77(4), 755-791. https://doi.org/10.2308/accr.2002.77.4.755

Beneish, M. D., Press, E., \& Vargus, M. E. (2004). Insider trading and incentives to manage earnings. Available at SSRN 495862. http://dx.doi.org/10.2139/ssrn.495862

Bhundia, A. (2012). A comparative study between free cash flows and earnings management. Business Intelligence Journal, 5(1), 123-129.

Chang, S. C., Chen, S. S., Hsing, A., \& Huang, C. W. (2007). Investment opportunities, free cash flow, and stock valuation effects of secured debt offerings. Review of Quantitative Finance and Accounting, 28(2), 123-145.

Charitou, A., Lambertides, N., \& Trigeorgis, L. (2007). Managerial discretion in distressed firms. The British Accounting Review, 39(4), 323-346. https://doi.org/10.1016/j.bar.2007.08.003

Cheng, Q., \& Warfield, T. D. (2005). Equity incentives and earnings management. The Accounting Review, 80(2), 441-476. https://doi.org/10.2308/accr.2005.80.2.441

Choi, M. (2016). Are Discretionary Accruals Signal for the Bright Future? Evidence from Information Demand and Supply Matrix. http://dx.doi.org/10.2139/ssrn.2856240

Christie, A. A., \& Zimmerman, J. L. (1994). Efficient and Opportunistic Choices of Accounting Procedures: Corporate Control Contests. The Accounting Review, 69(4), 539.

Core, J. E. (2001). A review of the empirical disclosure literature: discussion. Journal of accounting and economics, 31(1-3), 441-456. https://doi.org/10.1016/S0165-4101(01)00036-2

DeAngelo, H., DeAngelo, L., \& Skinner, D. J. (1994). Accounting choice in troubled companies. Journal of accounting and economics, 17(1-2), 113-143. https://doi.org/10.1016/0165-4101(94)90007-8

DeFond, M. L., \& Jiambalvo, J. (1994). Debt covenant violation and manipulation of accruals. Journal of accounting and economics, 17(1-2), 145-176.

Del Brio, E. B., Lopes-e-Silva, I., \& Perote, J. (2016). Effects of opportunistic behaviors on security markets: an experimental approach to insider trading and earnings management. Economia Politica, 33(3), 379-402.

Dichev, I. D., \& Skinner, D. J. (2002). Large-sample evidence on the debt covenant hypothesis. Journal of accounting research, 40(4), 1091-1123. https://doi.org/10.1111/1475-679X.00083

Farshadfar, S., \& Monem, R. (2011). Discretionary accruals and the predictive ability of earnings in the forecast of future cash flows: Evidence from Australia. Corporate Ownership and Control, 9(1), 597-608. DOI:10.22495/cocv9i1c6art3

Francis, J., LaFond, R., Olsson, P., \& Schipper, K. (2005). The market pricing of accruals quality. Journal of accounting and economics, 39(2), 295-327. DOI: 10.1016/j.jacceco.2004.06.003

Gul, F. A., Chen, C. J., \& Tsui, J. S. (2003). Discretionary accounting accruals, managers' incentives, and audit fees. Contemporary Accounting Research, 20(3), 441-464. https://doi.org/10.1506/686E-NF2J-73X6-G540

Gul, F. A., Leung, S., \& Srinidhi, B. (2000). The Effect of Investment Opportunity Set and Debt Level on Earnings-Returns Relationship and the Pricing of Discretionary Accruals. SSRN Working Paper Series. https://doi.org/10.2139/ssrn.236080

Habib, A., Uddin Bhuiyan, B., \& Islam, A. (2013). Financial distress, earnings management and market pricing 
of accruals during the global financial crisis. Managerial Finance, 39(2), 155-180. https://doi.org/10.1108/03074351311294007

Hosseini, M., Chalestori, K. N., Hi, S. R., \& Ebrahimi, E. (2016). A study on the relationship between earnings management incentives and earnings response coefficient. Procedia Economics and Finance, 36, 232-243. https://doi.org/10.1016/S2212-5671(16)30034-X

Howe, J. S., \& Houston, R. (2015). Earnings management, earnings surprises, and distressed firms. Accounting and Finance Research, 5(1), 64. https://doi.org/10.5430/afr.v5n1p64

Jaggi, B., \& Tsui, J. (2007). Insider trading, earnings management and corporate governance: empirical evidence based on Hong Kong firms. Journal of International Financial Management \& Accounting, 18(3), 192-222. https://doi.org/10.1111/j.1467-646X.2007.01012.x

Janin, R. (2000). Gestion des chiffres comptables, contenu informationnel du résultat et mesure de la création de valeur. Grenoble 2, (Unpublished doctoral dissertation).

Janin, R., \& Piot, C. (2008). L'influence des auditeurs externes et des comités d'audit sur le contenu informatif des manipulations comptables. La Revue des Sciences de Gestion, (5), 23-33.

Jelinek, K. (2007). The effect of leverage increases on earnings management. The Journal of Business and Economic Studies, 13(2), 24.

Jensen, M. C., \& Meckling, W. H. (1976). Theory of the firm: Managerial behavior, agency costs and ownership structure. Journal of Financial Economics, 3(4), 305-360. https://doi.org/10.1016/0304-405X(76)90026-X

Jiraporn, P., Miller, G. A., Yoon, S. S., \& Kim, Y. S. (2008). Is earnings management opportunistic or beneficial? An agency theory perspective. International Review of Financial Analysis, 17(3), 622-634. https://doi.org/10.1016/j.irfa.2006.10.005

Koussis, N., \& Makrominas, M. (2015). Growth options, option exercise and firms' systematic risk. Review of Quantitative Finance and Accounting, 44(2), 243-267. https://doi.org/10.1007/s11156-013-0405-5

Krishnan, G. V. (2003). Audit quality and the pricing of discretionary accruals. Auditing: A Journal of Practice \& Theory, 22(1), 109-126. https://doi.org/10.2308/aud.2003.22.1.109

Lee, C.-W. J., Li, L. Y., \& Yue, H. (2006). Performance, growth and earnings management. Review of Accounting Studies, 11(2-3), 305-334. http://doi.org/10.1007/s11142-006-9009-9

Liu, Y., \& Jiraporn, P. (2010). The effect of CEO power on bond ratings and yields. Journal of Empirical Finance, 17(4), 744-762. https://doi.org/10.1016/j.jempfin.2010.03.003

McNichols, M. F., \& Stubben, S. R. (2008). Does earnings management affect firms' investment decisions? The Accounting Review, 83(6), 1571-1603. https://doi.org/10.2308/accr.2008.83.6.1571

Moradi, J., Valipour, H., \& Pahlavan, Z. (2012). Earnings Management, Board Independence And Audit Fees Considering The Firm's Profitability Level. Asian Economic and Financial Review, 2(2), 358-366.

Nekhili, M., Amar, I. F. B., Chtioui, T., \& Lakhal, F. (2016). Free cash flow and earnings management: The moderating role of governance and ownership. The Journal of Applied Business Research, 32(1), 255-268. http://dx.doi.org/10.2139/ssrn.2546877

Nuryaman. (2013). The Influence of Earnings Management on Stock Return and the Role of Audit Quality as a Moderating Variable. International Journal of Trade, Economics and Finance, 4(2), 73-78. https://doi.org/10.7763/IJTEF.2013.V4.263

Ohlson, J. A. (1980). Financial Ratio and the Probabilistic Prediction of Bankruptcy. Journal of accounting research, 18(1), 109-131. https://doi.org/10.2307/2490395

Olsen, L., \& Zaman, M. (2013). Insider trading and motivations for earnings management. Journal of Accounting and Finance, 13(3), 51-66.

Omid, A. M. (2012). Type of Earnings Management and the Effects Debt Contracts, Future Earnings Growth Forecast and sales Growth: Evidence From Iran. School of Doctoral Studies (European Union), 7-16.

Rezaei, F., \& Roshani, M. (2012). Efficient or opportunistic earnings management with regards to the role of firm size and corporate governance practices. Interdisciplinary Journal of Contemporary Research in Business, 3(9), 1312.

Robin, A., \& Wu, Q. (2015). Firm growth and the pricing of discretionary accruals. Review of Quantitative 
Finance and Accounting, 45(3), 561-590. https://doi.org/10.1007/s11156-014-0447-3

Rosner, R. L. (2003). Earnings manipulation in failing firms. Contemporary Accounting Research, 20(2), 361-408. https://doi.org/10.1506/8EVN-9KRB-3AE4-EE81

Ross, S. A. (1977). The Determination of Financial Structure: The Incentive-Signalling Approach. Bell Journal of Economics, 8(1), 23-40. https://doi.org/10.2307/3003485

Rusmin, R., W. Astami, E., \& Hartadi, B. (2014). The impact of surplus free cash flow and audit quality on earnings management: The case of growth triangle countries. Asian Review of Accounting, 22(3), 217-232. https://doi.org/10.1108/ARA-10-2013-0062

Siregar, S. V., \& Utama, S. (2008). Type of earnings management and the effect of ownership structure, firm size, and corporate-governance practices: Evidence from Indonesia. The international journal of accounting, 43(1), 1-27. https://doi.org/10.1016/j.intacc.2008.01.001

Sloan, R. (1996). Do stock prices fully reflect information in accruals and cash flows about future earnings? Accounting review, 71(3), 289-315.

Smith, R. L., \& Kim, J. H. (1994). The combined effects of free cash flow and financial slack on bidder and target stock returns. Journal of business, 281-310.

Subramanyam, K. (1996). The pricing of discretionary accruals. Journal of accounting and economics, 22(1), 249-281. https://doi.org/10.1016/S0165-4101(96)00434-X

Thomas, S. (2002). Firm diversification and asymmetric information: evidence from analysts' forecasts and earnings announcements. Journal of Financial Economics, 64(3), 373-396. https://doi.org/10.1016/S0304-405X(02)00129-0

Xie, H. (2001). The mispricing of abnormal accruals. The Accounting Review, 76(3), 357-373. https://doi.org/10.2308/accr.2001.76.3.357

\section{Copyrights}

Copyright for this article is retained by the author(s), with first publication rights granted to the journal.

This is an open-access article distributed under the terms and conditions of the Creative Commons Attribution license (http://creativecommons.org/licenses/by/4.0/). 